\title{
Major phonemic problems of Bangladeshi learners of English: Reasons behind and solutions
}

\author{
A K M Mazharul Islam ${ }^{\bowtie}$ \\ College of Languages and Translation, King Khalid University, Kingdom of Saudi Arabia
}

\begin{tabular}{l} 
Article Info \\
\hline Article History: \\
Received in 16 Februari \\
2021 \\
Approved in 28 March \\
2021 \\
Published in 29 March \\
2021 \\
\hline Keywords: consonant \\
and vowel sounds; \\
sound production; \\
phonemic problem of \\
Bangladeshi learners; \\
differences and \\
difficulties
\end{tabular}

\begin{abstract}
The issue of Bangladeshi EFL learners' phonemic challenges, though not very battered, has been addressed by some researchers at different times. Even after having a prolonged history of learning and teaching and some research in the field, awkward pronunciations and misunderstandings are still prevailing everywhere, from the primary level to tertiary level and beyond. This study is undertaken to heighten the importance of delving deeper into the root causes of phonemic difficulties of the learners and to pinpoint the major problems. To add flesh to the theoretical skeleton of the topic a group of university students was interviewed along with a questionnaire to check their understanding of English phonology along with some other basic questions related to pronunciation. It can firmly be stated that teaching/learning pronunciation and hence starting from the segmental level has never been followed. Like any other country where English is in the status of a second language or foreign language, it is very natural to face difficulties to master the intricate phonemic features of the target language for the learners. Supposedly, it mostly results from the lack of knowledge of phonology and phonetics of the target language and due to the phonemic differences between the first language and the target language. In this study, the focus is kept mainly on the salient phonemic challenges faced by Bangladeshi learners of English. Bringing in the basic ideas of consonant and vowel sounds, the sound production mechanism is shown, and then the differences between the vowels and consonants of two languages are held out. Tracing out the key difficulties, some suggestions are provided. This writing is expected to be of considerable and comprehensive help for the instructors as well as for the interested learners and crucial addition to the literature of the topic.
\end{abstract}




\section{INTRODUCTION}

Language is a sublime gift to human beings since Language is the species-specific and species-uniform feature of the human being (Varshney, 2000). Vowels and consonants are the bricks of the great edifice of language within which dwell our thoughts and dreams, prayers and meditations, relation and communication. Proper understanding of vowel and consonant sounds is at the root of expertise in spoken skill. Bangladeshi learners of English usually face some difficulties as the language is not their mother tongue.

Though Bangla and English are the offspring of the same language family, namely Indo-European, more particularly, English descends from the Germanic group, whereas Bangla belongs to the Indo-Aryan group and is derived from Sanskrit. With the passage of time, English and Bangla have developed in their own ways. Each with its own characteristics in sounds, in words and sentence structures, in stress and intonation today they are entirely different languages (Fergluson, Hai, \& Ball, 1962). The study was triggered by few fundamental questions. Firstly, the question pursued is 'what are the major segmental differences between the target language and mother tongue?'. Secondly, the question, 'what difficulties do the learners face in learning the pronunciation of the target language?' is handled. Thirdly, the factors causing those difficulties are tried to be traced. At the very end, answers to the question- 'what are the probable solution to these problems?' are looked for. This study is an addition in the stream of the topic and an effort to lay further emphasis for taking the issue with more seriousness and an appeal to the concerned stakeholders to address the problem institutionally, embracing it in the materials and making it an integral part of the pedagogy of the discipline.

The history of institutional teaching-learning of English can be traced far back to the colonial period. The whole timespan of English learning and teaching in Bangladesh can be broadly categorized into three phases. The first period covers till 1947 up to independence from British rule. The second period, during the regime of newly created Pakistan, covers the postcolonial period ranging from 1947 to 1971. The third phase is from the independence of Bangladesh till now, starting from 1971 onward (Islam \& Hashim, 2019). Interesting enough, teaching pronunciation had never been taken into consideration.

The credit for early elementary work on Bangla phonetics supposedly goes to Chatterji (Chatterji, 1921) where he has elaborated the segmental and suprasegmental features of the language in considerable detail and minuteness. Ferguson et al. (Ferguson et al., 1962) have held out the basic differences between English and Bangla. They also have clearly shown the phonetic inventory of the two languages side by side at a very early time. These early works have not shed enough light to find out the causes of the difficulties of the learners. Haque (Haque, A., \& A., 1990), Rahman (Rahman A. H., 1996) have mentioned few major issues of the learners like the learners' using mother tongue accent for the target language without following sound pattern, accent and intonation. Failure to differentiate between long and short vowel is another notable flaw of the learners. Mujaffar (Mujaffar, 1999) has also observed the learners' difficulties with /z/, /ds/, /ff/, /v// /3/; / $/$ and / $/$ /; /t/ sounds. Banu (Banu, 2000) along with these problems has also discussed the issue of learners' inability to handle the features of aspiration and stress. Barman (2011) in his work has shown the contrastive features of the two languages concerned. He has not included the causes of the difficulties. Monjur and Uddin (2015) have shown the effects of dialects on the learners' output. They have pointed out that except for few regions the same tendency is observable among the learners. Tahreen (2015), Osmany (2017) have discussed the issue from the teacher's perspective and thrown some light on the challenges of teaching pronunciation in Bangladesh.

The comprehensibility and intelligibility of the spoken language is highly dependent on its pronunciation (Morley, 1991). Despite pronunciation being the most integral element of oral communication and communicative competence, this sub-skill of English has always been neglected in Bangladesh (Maniruzzaman, 2008; Osmany, 2017; Tahereen, 2015). Recent studies are conducted mainly from the teaching point of view to find out the challenges in teaching pronunciation. Early works on the topic dealt mainly with differences between two sets of phonemes. A deeper understanding of the segmental features of the target language is very crucial. Awareness of the segmental differences between mother tongue and target language is at the root of mastering the proper pronunciation of the target language and hence, this study narrowed down the focus on the major phonemic differences and difficulties from the learners' standpoint and comes up with some pedagogical implications in the end. Though various aspects of English language teaching have been covered by researchers at different times, enough research on the topic has not been done. In this respect, this study is expected to play an important role by providing the stakeholders an insight and pave the way to better learning/teaching.

\section{Sound Production Mechanism}

Before we explore the segmental difficulties let us have a glance at the sound production mechanism which is regarded indispensable to the study of phonetics. The production of any sound is not as simple as merely 
opening and closing the mouth. It is a rather complex process. Three stages are involved here psychological, physiological and physical. In the psychological stage, when we try to produce any sound then a group of brain cells is excited, and a message is formed. Then in the physiological level, the message is carried to the diaphragm. In the third level, which is in the physical level, the message is passed to the diaphragm. The diaphragm gives a squeeze and a flow of air rushes out through the windpipe and is finally released either through the oral cavity or nasal cavity (Sethi \& Dhamija, 1998). In the case of consonant sounds, the flow of the air is obstructed almost at a dozen places. But regarding vowel sounds, that flow of air is not hindered anywhere and directly let out in the air (Yule, 2008). The following figures would help us to understand the production of consonant and vowel sounds. To produce any sound, the diaphragm starts the physical process by throwing the airflow outward; The thrown air then passes by various articulators. The flow of the air is being played by a group of active and passive articulators for producing consonant sounds. If the airstream is directly emitted to the air without having any blockage or obstruction, then vowel sounds are produced. The following fundamental figure as presented in Islam (2017) is a placeworthy one.

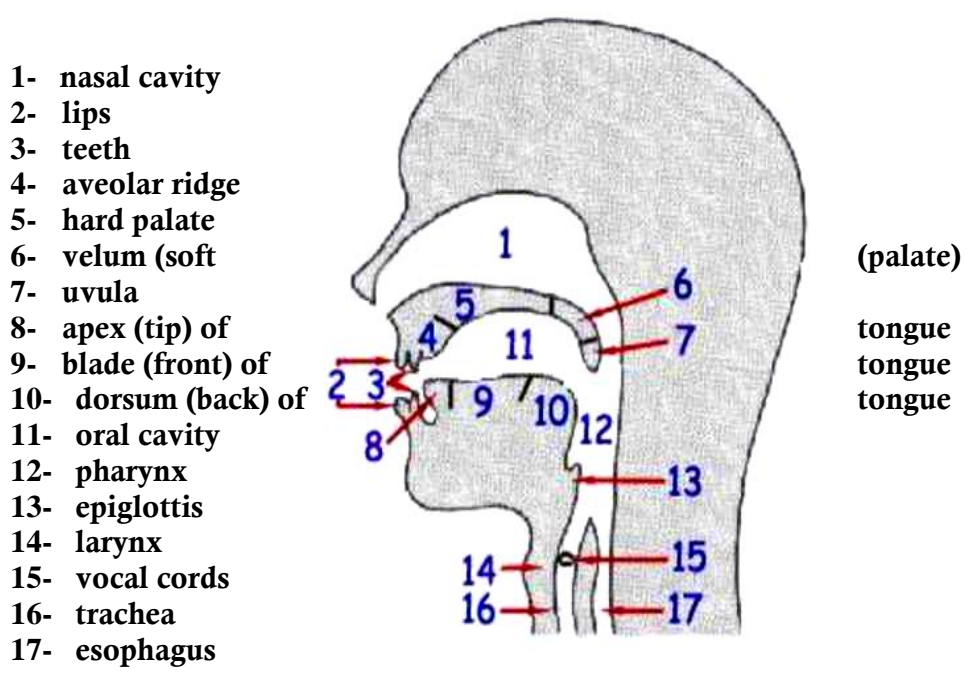

Figure 1. The organs of speech

\section{Basic Sounds of English}

All the speech sounds created by human beings are broadly divided into two categories- vowels and consonants. A vowel is a hum or a tune which is produced with the thrown air stream of the lungs and the airflow is not hindered anywhere from the voice-box to lips and no audible friction is caused. In other words, vowels are sounds that are produced when the airflow from the lungs passes through the larynx without any obstruction anywhere (Sethi \& Dhamija, 1998). So, we can say that vowels are sounds that are articulated without any obstruction, partial or complete, in the oral cavity. The vowels can be monophthongs, diphthongs and triphthongs regarding their quality. The monophthongs or the pure vowels can again be divided into long and short categories in respect of their length. Lip rounding and tongue advancement and height also add to the subtle features of vowels. Consonants, on the other hand, are the sounds in the production of which there is an obstruction or a constriction in the airstream. Consonants are divided into various types according to places and manners of articulation. The vibration of the vocal folds at the time of articulation divides all the consonants into voiced and voiceless types again. The number of speech sounds varies from language to language. In English, according to most accounts, there are 49 phonemes including the triphthongs. There are 12 vowels, 8 diphthongs, 5 triphthongs and 22 consonants (Roach, 2000). It is very hard to ascertain the exact number of Bangla phonemes due to controversies among linguists working with Bangla phonology. According to Chatterji (1921) the number of the essential phonemes of standard colloquial Bangla it is 35. A recent account of the Bangla phonemes shows the number to be 62 (Hasan, 1995). They are 7 oral vowels, 7 nasal vowels, 18 diphthongs and 30 consonants.

\section{METHODS}

The qualitative approach was mainly adopted for this study. Fifty student respondents were randomly chosen from two private universities of Bangladesh. They were all first year first-semester students of BA 
in English program, both male and female, age ranging from seventeen to twenty-two. They did not attend any course on pronunciation or phonetics in the department by that time or before at any other stage of their study. In a formal setting, the students were asked to read a script with a list of words including the vowel and consonant sounds of English. Particularly the words with sounds which were thought to be challenging had mostly been given. Their readings were recorded and analyzed. An analysis especially of their common mistakes was also made and presented in the discussion section.

Recordings of structured/semi-structured interviews, class/presentation observation is a common practice in the study of phonetics, particularly in the study of segmental and suprasegmental features of any language. Like many other researchers, Haque and Begum (Hoque \& Begum, 2016), Goswami (Goswami, 2020) maintain the same tool in their studies. The instrument type of the study is very common and widely used and hence, it is expected to satisfy the validity and reliability concerns. The reading script was developed with a special focus on the words with the sounds that are absent in the learners' mother tongue. Regarding the consonants, words like 'vine', 'think', 'zero', 'measure', 'war' and 'yes' were given to check the pronunciation of the sounds $/ \mathrm{f} /, / \mathrm{v} /, / \theta /, / \mathrm{z} /, / 3 /, / \mathrm{w} /, / \mathrm{j} /$ respectively. Words with consonant sounds that are absent in the target language were also included. In respect of the vowel sounds, words were selected following the same principle with special importance on the words with /ə/, long vowels and diphthongs. Learners' attempts are presented in the tables in the discussion section. The respondents were also asked some elementary questions related to English language learning in general and the importance of learning pronunciation. Permissions were duly taken to use the samples for research purposes, and they were also ascertained of the confidentiality of their identity.

In the study, the knowledge of the segmental features of English language is briefly discussed. Then, the segmental differences of the target language and mother tongue are held out. After that, effort is taken to diagnose the phonemic difficulties of the learners. It is also tried to track down the reasons behind these difficulties. And finally, some pedagogical suggestions are offered for consideration.

\section{FINDINGS AND DISCUSSION}

\section{Learners' Difficulties with English Vowels}

Islam (2018) observes that a speaker's articulators usually get set with the sounds of his/her mother tongue. When he tries to learn a language other than his mother tongue then he faces problems with those sounds that are not found in his tongue. Several problems may be traced regarding vowel sounds. One of the remarkable problems of $\mathrm{BD}$ learners of English is that his mother tongue vowels often intrude into the target language vowels. Another problem is the learners cannot handle long and short vowels. In Bangla long and short vowels do not make any difference in meaning usually. It is rather a phonetic feature than phonemic. In English they are very crucial.

We have noted that the quality of a Bengali vowel is not conditioned by length. On the other hand, length distinguishes English vowel sounds, / i- i:, o- o:, u- u: /. Bengali speakers do not usually make any distinctions between short and long vowels. For example, they pronounce /ful/ and /full/ in the same way (Haque, 1990, p. 101).

Some of the vowels in English are not there in Bangla. Schwa ' $\partial$ ' is a characteristic sound which becomes very tricky for the learners. Long vowels /a:/, / // are also difficult to tackle. Another noticeable difficult area for the learners is diphthongs. Davenport (Davenport \& H., 2010) mentions that the strong feature of English diphthongs is the glides from one vowel to the other. The common mistake that is made by the learners is that they only say the first part of the diphthong and ignore the second part and in consequence, they sound like a short vowel. In respect of diphthongs, similar to Tahreen's (2015) findings, learners pronounce the diphthongs as monophthongs. Last part of the sound is missed. They pronounce /go/ for /gov/, /mek/ for /meik/ and the like. Yet, the learners were not able to handle the triphthongs and were mostly not aware of them. They are found in the words like eI + ə $=$ eІә(player) aI $+\partial=$ aIə(fire)

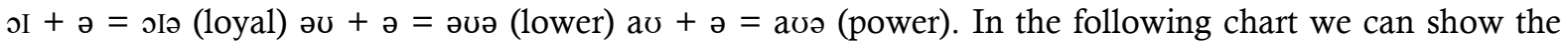
difficulties in brief:

Table 1. Attempts of the Bengali learners of the English Vowels

\begin{tabular}{|c|c|c|c|}
\hline $\begin{array}{l}\text { Sounds in } \\
\text { English }\end{array}$ & $\begin{array}{l}\text { Example in } \\
\text { words }\end{array}$ & $\begin{array}{c}\text { Correct } \\
\text { pronunciation }\end{array}$ & Attempt of the learners and notes \\
\hline $\mathrm{i}:, \mathrm{i}$ & Feel, fill & /fi:1/,/fIl & $\begin{array}{l}\text { /fi 1/ both long and short becomes the } \\
\text { same, they use their only vowel }\end{array}$ \\
\hline $\mathrm{a}:, \Lambda, 3:$ & bard, bud, bird & $\begin{array}{c}/ \mathrm{ba}: \mathrm{d} / \mathrm{b} 3: \mathrm{b} / \mathrm{d} / \\
\end{array}$ & $\begin{array}{l}\text { /bad/; in all cases they use only /a/ } \\
\text { sound }\end{array}$ \\
\hline
\end{tabular}




\begin{tabular}{|c|c|c|}
\hline ə & about & $/ \mathrm{sb}_{\Lambda} \mathbf{v} /$ \\
\hline o: & saw & /so:/ \\
\hline $\mathrm{u}, \mathrm{u}:$ & full, fool & /ful/, /fu:1/ \\
\hline еə, Iə, uə & air, fear, poor & /eə/, /fгə/, /pu \\
\hline
\end{tabular}
$/ \mathrm{ab} \Lambda \mathbf{v} /$; learners use 3rd Bengali
vowel

/so / learners use their own vowel 5
/ful/ ; both cases only Bangla vowel no 7 is used

The learners usually break the diphthongs in their own vowels and first made long; becomes very different from the right one

\section{Discussion on Difference Between English and Bangla Vowels}

To be aware of the difficulties of Bangladeshi learners of English we are to be familiar with the differences between Bangla and English vowels. There are some vowels of English which are not present in Bangla and the Vice-versa. In Bangla alphabet though the feature long and short is mentioned but it is not maintained in pronunciation. The intermingling between short and long vowels does not make any difference in meaning but this is not the case in English. The use of short vowels in place of long ones and the vice-versa may be a blunder. The meaning may be altogether different with the change of long and short vowels. Diphthongs of these two languages are also not the same. Whereas English has 8 diphthongs Bengali has 18 regular diphthongs (Ferguson et al., 1962). The Bangla diphthongs are far greater in number than English diphthongs. Another point of difference is that unlike English vowels Bangla vowels can be nasalized and can affect the meaning. The following table can be helpful:

Table 2. Difference between Bangla and English vowel sounds.

\begin{tabular}{llll}
\multicolumn{2}{c}{ T: Present; X: not present } & \\
\hline Phonetic Symbol & English & Bangla & Key Word \\
\hline $\mathbf{i}:$ & $\mathrm{T}$ & $\mathrm{X}$ & Feel \\
$\mathbf{i}$ & $\mathrm{X}$ & $\mathrm{T}$ & chil (eagle) \\
$\mathbf{i}$ & $\mathrm{T}$ & $\mathrm{X}$ & Fill \\
$\mathbf{e}$ & $\mathrm{T}$ & $\mathrm{T}$ & Bed \\
$\mathbf{x}$ & $\mathrm{T}$ & $\mathrm{T}$ & Cat \\
$\mathbf{a}$ & $\mathrm{X}$ & $\mathrm{T}$ & bhat (rice) \\
$\mathbf{a}:$ & $\mathrm{T}$ & $\mathrm{X}$ & Part \\
$\mathbf{p}$ & $\mathrm{T}$ & $\mathrm{T}$ & Hot \\
$\mathbf{o}$ & $\mathrm{X}$ & $\mathrm{T}$ & gol(round) \\
$\mathbf{v}$ & $\mathrm{T}$ & $\mathrm{X}$ & Full \\
$\mathbf{u}:$ & $\mathrm{T}$ & $\mathrm{X}$ & Fool \\
$\mathbf{u}$ & $\mathrm{X}$ & $\mathrm{T}$ & chul (hair) \\
$\mathbf{A}$ & $\mathrm{T}$ & $\mathrm{X}$ & But \\
$\mathbf{3 :}$ & $\mathrm{T}$ & $\mathrm{X}$ & Third \\
$\mathbf{0}$ & $\mathrm{T}$ & $\mathrm{X}$ & Above \\
$\mathbf{0 : / \mathbf { 0 } :}$ & $\mathrm{T}$ & $\mathrm{X}$ & Saw \\
\hline
\end{tabular}

The following quadrant would help us to understand the comparative spots where from the vowels of two languages are produced. Some of the vowels conform in their positions but some are not identical.

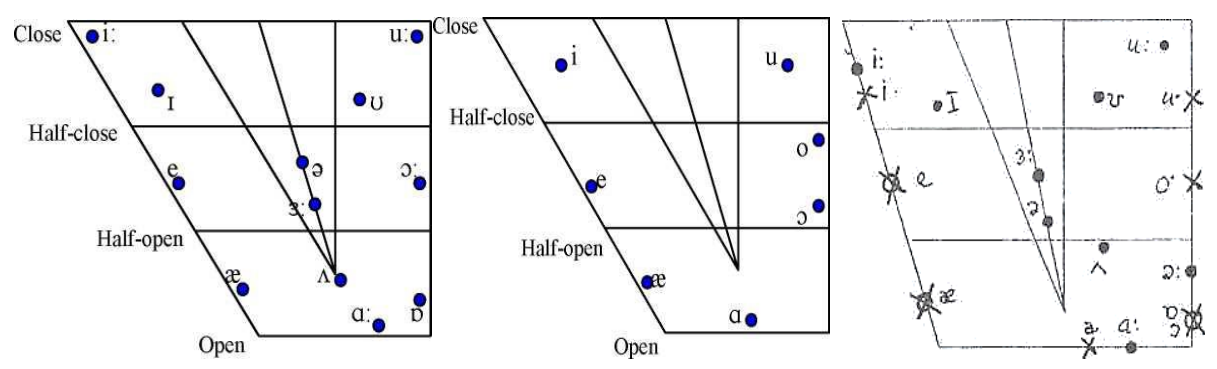

Quadrant 1. English vowel (Barman, 2011)

Quadrant 2. Bangla Vowel (Barman, 2011)

Quadrant 3. relative positions of English and Bangla vowels from (Ferguson et al., 1962)

Figure 2. Quadrans of the vowels 


\section{Learners' Difficulties with Consonants}

Some problems can be traced regarding consonant sounds. In this respect, a noteworthy thing is that the problem often arises due to the knowledge of L-1 interference. The mistakes the learners make are listed below:

- In place of 'flower', 'fine' 'full' they pronounce it 'phlauar' 'phine' and 'phull'. Here we see labiodental sound /f/ becomes bilabial / $\mathrm{p}^{11} /$

- 'vast' /va:st/, 'van' /vaen/ become /bhtsn/ and Must/. Labio-dental /v/ becomes bilabial plosives $/ \mathrm{w} /$ and $/ \mathrm{y} /$ are not properly pronounced. They are treated as vowels rather than consonants. In place of 'water' /wo:tə/ they say /ot $\Lambda \mathrm{r} /$.

- Common speaker mostly pronounces the final $/ \mathrm{r} /$ of the syllable.

- Interdental / $\theta$ / often made alveolar thus / $\theta$ Ink/ becomes / think/.

- Interchangeability between some pair sounds in different regions of the country- /s - $\int /$ $/ \mathrm{f}-\mathrm{p}^{\mathrm{h}} /, / / \mathrm{b}^{\mathrm{h}}-\mathrm{v} / / \mathrm{3}-\mathrm{d} 3 /$

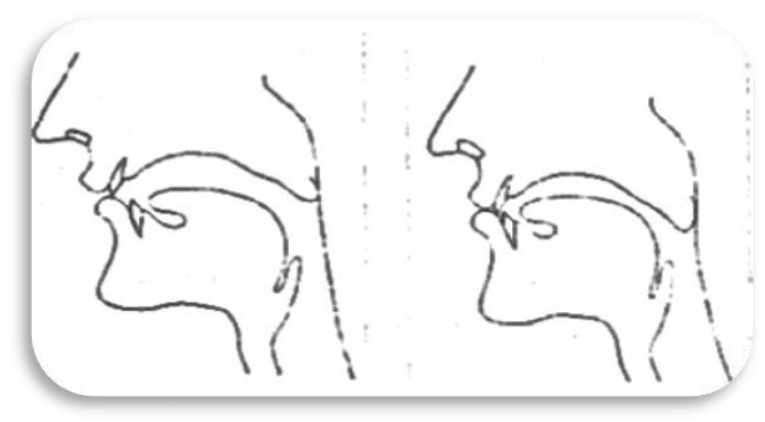

Figure 3. (a) labio-dental (b) bilabial (Roach, 2000)

Major difficulties are presented in the following table.

Table 3. Bangladeshi learners' attempt of English consonants

\begin{tabular}{|c|c|c|c|}
\hline $\begin{array}{c}\text { Sounds in } \\
\text { English }\end{array}$ & Example in words & $\begin{array}{c}\text { Correct } \\
\text { pronunciation }\end{array}$ & Attempt of the learners and notes \\
\hline$/ \mathrm{f} /$ & fine & /fain/ & $\begin{array}{l}\text { it is pronounced as /phain/ using } \\
\text { aspirated Bangla bilabial consonant }\end{array}$ \\
\hline$/ \mathrm{v} /$ & van & /væn/ & $\begin{array}{l}\text { It is pronounced as /bitten/ with } \\
\text { bilabial /bh/ }\end{array}$ \\
\hline$/ 3 /$ & pleasure & /'plezə/ & $\begin{array}{l}\text { It becomes /plejar/ or /plezar/, here } \\
\text { the } / \mathrm{z} / \text { becomes plosive } / \mathrm{z} / \text { or affricate } \\
/ \mathrm{j} /\end{array}$ \\
\hline$/ \mathrm{w} /$ & wash & $/ / \mathrm{wp} f /$ & $\begin{array}{l}\text { It becomes } / \mathrm{\rho} \int / \text {, bilabial English } \\
\text { consonant } / \mathrm{w} / \text { is completely ignored }\end{array}$ \\
\hline$/ \mathrm{j} /$ & yes & /jes/ & $\begin{array}{c}\text { It becomes } / \text { ies } / \text { ommitteng the palatal } \\
\text { consonant } / j /\end{array}$ \\
\hline$/ \mathrm{r} /$ & barber & /ba:b?/ & $\begin{array}{l}\text { It becomes /ba:rba:r/, final } I d \text { is mostly } \\
\text { pronounced }\end{array}$ \\
\hline$|z|$ & Zeep/zoo & /zi:p/ /zu:/ & It becomes / dzip/, /dzu/ \\
\hline
\end{tabular}

Islam (2017) summarizes the problems nicely. He points out that sounds $/ \mathrm{p} /, / \mathrm{t} /, / \mathrm{k} /$ are different from Bangla counterparts $/ \mathrm{p} /($ ( ), $/ \mathrm{t} /(\mathrm{t})$, and $/ \mathrm{k} /($ ক) in respect of aspiration. He presents the differences and the difficulties hierarchically. 


\begin{tabular}{|c|c|c|c|}
\hline \begin{tabular}{|ll} 
The difficult & English \\
consonants & \\
\end{tabular} & Number & $\begin{array}{l}\text { Aspects/Descriptions of difference and } \\
\text { difficulty }\end{array}$ & Remark \\
\hline $\begin{array}{l}/ \mathrm{h} /, / \mathrm{m} /, / \mathrm{g} / / \mathrm{d} /, / \mathrm{b} / \\
/ \mathrm{g} /, / \mathrm{S} /\end{array}$ & Seven & No difference & No difficulty \\
\hline$/ \mathrm{n} /, / \mathrm{s} /, / \mathrm{w} /, / \mathrm{j} /$ & Four & $\begin{array}{l}\text { Place of articulation (1st two); the next } \\
\text { two (semivowels, bilabial and palatal } \\
\text { respectively) are not available in Bengali }\end{array}$ & Insignificant difficulty \\
\hline$/ / \mathrm{p}^{\mathrm{h} / /, / \mathrm{t}^{\mathrm{b}} /, / \mathrm{k}^{3} /}$ & Three & Aspiration & Somewhat difficult \\
\hline$/ 1 /$ & One & Place of articulation & Significantly difficult \\
\hline$/ 8 /, / \theta /$ & Two & Manner of articulation & Very difficult \\
\hline$/ \mathrm{s} /, / \mathrm{f} /, / \mathrm{v} / \mathrm{t}\left[/ /, / \mathrm{dz}_{3} /\right.$ & Five & Both place and manner of articulation & $\begin{array}{l}/ \mathrm{v} / \text { is the most difficult } \\
\text { in this group }\end{array}$ \\
\hline$/ \mathbf{2} /, / 3 /$ & Two & Unavailability in Bengali & $\begin{array}{l}/ 3 / \text { is the most difficult } \\
\text { of all of the sounds } \\
\text { listed }\end{array}$ \\
\hline
\end{tabular}

Figure 4. Image of a table of difficult English consonants Islam (2017)

\section{Discussion on Findings Regarding Consonants}

There are many consonants in Bangla and English which click with each other, yet there are some which are not so. Some consonant sounds of English are missing in Bangla and some of the Bangla consonants, in the same way, are not found in English. Overlooking suprasegmental features of consonants, we can notice some major differences between the consonants of these two languages. There are six plosives in English. They are: $/ \mathrm{p} /, / \mathrm{b} /, / \mathrm{k} /, / 1 /, / \mathrm{g} /$ and $/ \mathrm{d} /$. Whereas, in Bangla, there are twenty plosive sounds. The intermingling of bilabial and labio-dental consonants of English is a common vulnerable area for Bangladeshi learners. The sound / $\mathrm{z} /$ is often replaced by Bangla $/ \mathrm{j} /$ sound. Affricates also become more and more plosives. The following table may be helpful to understand the major differences.

Table 4. Different Bangla and English consonants

T: Present; X: Not present

\begin{tabular}{ccccc}
\hline Sounds & Place of articulation & English & Bangla & Key Word \\
\hline$/ \mathrm{f} /$ & Labio-dental & $\mathrm{T}$ & $\mathrm{X}$ & fine \\
$/ \mathrm{v} /$ & Labio-dental & $\mathrm{T}$ & $\mathrm{X}$ & vine \\
$/ \theta /$ & Inter dental & $\mathrm{T}$ & $\mathrm{X}$ & think \\
$/ \mathrm{z} /$ & alveolar & $\mathrm{T}$ & $\mathrm{X}$ & zero \\
$/ \mathrm{3} /$ & Post alveolar & $\mathrm{T}$ & $\mathrm{X}$ & measure \\
$/ \mathrm{w} /$ & bilabial & $\mathrm{T}$ & $\mathrm{X}$ & war \\
$/ \mathrm{j} /$ & palatal & $\mathrm{T}$ & $\mathrm{X}$ & yes \\
$/ \mathrm{kh} /$ & Velar & $\mathrm{X}$ & $\mathrm{T}$ & 'Khaua'- eat \\
$/ \mathrm{gh} /$ & Velar & $\mathrm{X}$ & $\mathrm{T}$ & 'Gham' - sweat \\
$/ \mathrm{jh} /$ & Alveo- palatal (plosive) & $\mathrm{X}$ & $\mathrm{T}$ & 'Jhanu'- expert \\
$/ \mathrm{t} /$ & dental & $\mathrm{X}$ & $\mathrm{T}$ & 'Tala'- lock \\
$/ \mathrm{t} / \mathrm{h} /$ & dental & $\mathrm{X}$ & $\mathrm{T}$ & 'Thala'- plate \\
$/ \mathrm{d} /$ & dental & $\mathrm{X}$ & $\mathrm{T}$ & 'Dhoni'- rich \\
$/ \mathrm{ph} /$ & bilabial & $\mathrm{X}$ & $\mathrm{T}$ & 'Phol'- fruit \\
$/ \mathrm{bh} /$ & bilabial & $\mathrm{X}$ & $\mathrm{T}$ & 'Bhalo'- good \\
\hline
\end{tabular}


At this point we are looking for the causes behind the difficulties. We shall find a number of causes at work. When a learner wants to learn a different language other than his mother tongue then the main problem, he faces is his prior knowledge of $\mathrm{L} 1$; it intrudes every now and then. The age factor is also there (Roach, 2000), (UKEssays, 2018). Osmany (Osmany, 2017) mentions in her findings that though pronunciation is held very important by the learners and the teachers, it had never been taught, trained and tested. Let us try to enumerate the major causes:

- Knowledge of LI sound pattern interference

- Interference of regional accent

- Lack of awareness

- Lack of exposure

- Lack of knowledge of the sound pattern of sounds of English

- Alphabatic English spelling

- Lack of practice

- Lack of motivation

- Shortage of trained instructors

Some suggestions can rightly be offered at this stage. Though teaching/learning of English has a long history in Bangladesh which even dates back to the starting of the British colonial time (Islam \& Hashim, 2019), the teaching/learning pronunciation has never been considered. Of course, it is not very easy to master all the sounds of a language which is not one's mother tongue. The first job is to become aware of the problems. Once the problems are diagnosed then they can be faced easily. To handle them we can try the following suggestions:

- Making the learners aware of the differences

- Making the learners aware of their difficulties

- Making the learners aware of all the sounds along with their places and manners of articulation

- Finding out major problematic sounds

- Treating them one by one

- Engaging in more communicative activities

- Providing them with regular reinforcement

- Providing them a native or near-native model

- Providing them maximum positive exposure

In this respect, Harmer (Harmer, 2003) offers some suggestions to help the learners out. It is not possible to learn the pronunciation exactly like the native speakers. Some learners deliberately do not want to sound like the natives. So, he fixes intelligibility to be the target of the nonnative speaker learners. He lays much importance on listening since a learner will not be able to give the right pronunciation unless he can listen properly.

There are two ways of dealing with this: in the first place, we can show students how sounds are made through demonstration, diagrams, and explanation. But we can also draw the sounds to their attention every time they on a tape or in our own conversation. In this way, we gradually train the students' ears. When they can hear correctly, they are on the way to being able to speak correctly (Harmer, 2003, p. 185)

A guide or teacher is to determine when to teach pronunciation and he is to choose the best suitable class technique for his learners among the techniques like - whole lesson, discrete slot, integrated phase, and opportunistic teaching. And he also suggests the phonemic chart to be hung in the classroom near at hand. The learner can be instantly directed to the chart when some sounds are mispronounced or confused. Finally, he opines- "The key to successful pronunciation teaching, however, is not so much getting students to produce correct sounds or intonation tunes, but rather to have them listen and notice how English is spoken- either on audio or videotape or from the teachers themselves" (Harmer, 2003, p. 185). A syllabus designed Rahman (Rahman \& Chowdhury, 2019) for teaching pronunciation to Bangladeshi learners can rightly be placed here. 
Table 5. A model syllabus for teaching pronunciation to BD learners

\begin{tabular}{|c|c|c|}
\hline Id & Syllabus Item & Objective \\
\hline 0 & The human musical instrument & $\begin{array}{l}\text { Familiarize learners with } \\
\text { the Human Vocal Sound } \\
\text { making instrument }\end{array}$ \\
\hline 1 & Consonant sounds & \\
\hline 1.1 & The fricatives (voiced and unvoiced) & Address Problem 1 \\
\hline 1.2 & $\begin{array}{l}\text { English consonants which are replaced by similar } \\
\text { sounds from the L1 or from English— to address } \\
\text { Problem } 2\end{array}$ & Address Problem 2 \\
\hline 1.3 & Consonants $/ 1 /, / r /$, one form only Problem 3 & Address Problem 2 \\
\hline 2 & $\begin{array}{l}\text { Consonant clusters: non-deletion of the first } \\
\text { consonant in word initial clusters and no vowel } \\
\text { insertion at word initial position }\end{array}$ & Address Problem 4 \\
\hline 3 & $\begin{array}{l}\text { Nuclear stress: to be taught through songs. May be } \\
\text { left for the second stage after learners have mastered } \\
\text { items } 0 \text { to } 2 \text {. (Problem 7) }\end{array}$ & Address Problem 7 \\
\hline
\end{tabular}

Intelligibility and understandability should be the focus rather than perfection in pronunciation is the opinion of Tahreen (2015). She also offers a list of suggestions to overcome the problem like integrated pronunciation teaching from the beginning, introducing IPA symbols, comparing the sounds with the Bangla counterparts, commutative activities, using dictionaries, smartphones and computers and so on.

\section{CONCLUSION}

Language is a rare blessing shown to humankind and vowels and consonants are the souls of any language. When English is not the mother tongue, learning the sounds of the language is surely not an easy job. Receiving proper guidance, a careful and enthusiastic learner may acquire them with the expected accuracy. Taking the offered suggestions into consideration, one can minimize the obstacles and can maximize his learning of the sounds to the desired extent if not exactly like the natives. Our effort has been to find out the major problems of Bangladeshi learners with the sounds of English and to look for some solutions. Suprasegmental features are beyond the limit of this study and hence there are obvious scopes of future broader research. Connecting the old works with the recent ones, this mixed kind of study has been undertaken to add to the scanty body of available literature and above all, to give a comprehensive view of the issue to the concerned stakeholders.

\section{REFERENCES}

Banu, R. (2000). Bangladeshi English: a new variety? Journal of the Institute of Modern Languages, 6465 .

Barman, B. (2011). A Contrastive Analysis of English and Bangla Phonemics. Dhaka University Journal of Linguistics, 19-42.

Chatterji, S. K. (1921). Bengali Phonetics. Bulletin of the School of Oriental and African Studies, 2(1), 125. Retrieved from https://doi.org/10.1017/S0041977X0010179X

Davenport, M., \& H., S. J. (2010). Introducing Phonetics and Phonology. UK: Routledge.

Fergluson, C. A., Hai, M. A., \& Ball, W. J. (1962). The Sound Structures of English and Bengali. Language, 460-462.

Goswami, A. (2020). Changing Contours: The Interference of the Mother Tongue. The Journal of English as an International Language, 15(2). Retrieved from https://www.elejournals.com/eilj2020/volume-15-issue-2-2020/

Haque, S., A., E. B., \& A., A. (1990). Bengali Speech Sounds and Their Effects on EFL Learners' Pronunciation. BELTA JOURNAL.

Harmer, J. (2003). The Practice of English Language Teaching. Pearson Education Limited.

Hasan, A. D. (1995). The Segmental Phonemes of Bengali. Journal of the Institute of Bangladesh, 23-49.

Hoque, M. A., \& Begum, A. (2016). English Pronunciation Problems of Tertiary Level Students in Bangladesh: A Case Study. Journal of Arts, Science and Commerce, 7(4), 50-61. Retrieved from http://dx.doi.org/10.18843/rwjasc/v7i4/06 
Islam, A. (2018). A Comparative Study of English and Bangla Vowel System. Bulletin of Advanced English Studies, Refaad, 130-137. Retrieved from https://doi.org/10.31559/baes2018.1.2.1

Islam, M. N., \& Hashim, A. (2019). Historical Evolution of English in Bangladesh. Journal of Language Teaching and Research, 10(2), 247-255. Retrieved from https://doi.org/10.17507/jltr.1002.05

Islam, S. M. (2017). A Contrastive Analysis of English and Bengali Consonant. Journal of Education and Social Sciences, 159-170.

Maniruzzaman, M. (2008). Teaching EFL pronunciation. Why? What? And How? Munich, Germany: Grin Publishing.

Monjur, S., \& Uddin, M. N. (2015). The Influence of Regional Bangla Dialects on English Pronunciation. International Journal of Arts,, 11-23. Retrieved from http://ijahms.com:80/03.12.20151.pdf

Morley, J. (1991). The Pronunciation Component in Teaching English Speakers of Other Languages. TESOL Quarterly, 25(3), 481-520.

Mujaffar, T. B. (1999). On gees and Zees: A Comparative Phonological Study Towards Better English Pronunciation. Proceedings of the International Conference on National and Regional Issues in English Language Teaching: International Perspective (pp. 69-71). ELTIP.

Osmany, S. (2017). Factors Affecting Teaching Pronunciation at Tertiary Level. Dhaka: East West University. Retrieved from http://dspace.ewubd.edu:8080/bitstream/handle/2525/2750/Samira_Osmany.pdf?sequence $=1 \&$ isAllowed $=\mathrm{y}$

Rahman, A. H. (1996). Problems of Pronunciation For Bengali Learners of English. Journal of the Institute of Modern Languages, 1-15.

Rahman, A., \& Chowdhury, D. R. (2019). An ELF-based Syllabus for Teaching English Pronunciation to Native Bengali Speakers. BELTA Journal, 47-64.

Roach, P. (2000). English Phonetics and Phonology. Cambridge University Press.

Sethi, J., \& Dhamija, P. V. (1998). A Course in Phonetics and Spoken English. Prentice Hall Private Limited.

Tahereen, T. (2015). Challenges in Teaching Pronunciation at Tertiary Level in Bangladesh. Internation Journal of English Language and Translation Studies, 9-20.

UKEssays. (2018). Problems Faced by Asian Students in English Pronunciation. Problems Faced by Asian Students in English Pronunciation. UKEssays. Retrieved from https://www.ukessays.com/essays/education/problems-faced-by-asian-students-in-englishpronunciation-education-essay.php

Varshney, R. L. (2000). An Introductory Textbook of Linguistics and Phonetics. Student Store.

Yule, G. (2008). The Study of Language. Cambridge University Press. 